\title{
FOSSIL SAND DOLLARS (ECHINOIDEA: CLYPEASTEROIDA) FROM THE SOUTHERN BRAZILIAN COAST
}

\author{
RENATO PEREIRALOPES \\ Setor de Paleontologia, Instituto de Oceanografia, FURG, Campus Carreiros, 96201-900, Rio Grande, RS, Brasil. \\ paleonto_furg@yahoo.com.br
}

\begin{abstract}
Quaternary sediments along the southernmost portion of the Brazilian coast are rich in fossil remains of various terrestrial and marine organisms. This paper presents a description of fossil irregular clypeasteroid echinoids found in this area, with observations on their taphonomy. The identified taxa are Encope emarginata (Leske) and Mellita quinquiesperforata (Leske), although the latter is very scarce. All fossils consist of fragments of the test, broken along the ambulacral or interambulacral sutures. The majority of the remains consist of abraded fragments; petaloids are found either intact or collapsed. Many fossils are represented by internal molds formed by the infilling of the organisms' internal cavities by dark muddy matrix. The distribution of the fossils match the pattern observed on recent echinoid remains found along the coast. The relative absence of fossil and recent material of $M$. quinquiesperforata seems to be a result of taphonomic factors related to environmental processes.
\end{abstract}

Key words: Echinoidea, Clypeasteroida, Encope, Mellita, sand dollar, Quaternary.

RESUMO - O extremo sul da costa brasileira é uma área rica em fósseis contendo restos de diferentes organismos, tanto terrestres quanto marinhos. Neste trabalho é apresentada uma descrição de fósseis de equinoides irregulares encontrados nessa área, com observações sobre sua tafonomia. Os táxons identificados são Encope emarginata (Leske) e Mellita quinquiesperforata (Leske), embora este último seja muito escasso. Todos os fósseis consistem de fragmentos da testa quebrados ao longo das suturas ambulacrais ou inter-ambulacrais. A maioria dos restos está desgastada, e os petaloides encontram-se intactos ou colapsados. Muitos fósseis são moldes internos, formados pelo preenchimento das cavidades internas dos organismos por lama escura. A distribuição dos fósseis coincide com o padrão observado em equinoides recentes encontrados ao longo da costa. A ausência relativa de material fóssil e recente de $M$. quinquiesperforata aparentemente é resultado de fatores tafonômicos relacionados a processos ambientais.

Palavras-chave: Echinoidea, Clypeasteroida, Encope, Mellita, bolacha-da-praia, Quaternário.

\section{INTRODUCTION}

The irregular echinoids belong to the order Clypeasteroida. They are commonly known as sand dollars or keyhole urchins and include 150 extant species plus some 750 fossil species (Mooi, 1989). The clypeasteroids are predominantly epibenthic deposit-feeders that live between the intertidal and sublittoral zones. They are characterized by a flattened skeleton (test), convex on the dorsal (aboral) side and flattened or slightly concave on its ventral (oral) side. The flattened shape increases the surface area in contact with the substrate from which the animals obtain their food (Easton, 1960; Durham, 1966; Schäfer, 1972). They exhibit features such as the presence of openings or indentations in the test (lunules), which reduce the hydrostatic pressure of the flowing water over the test (Telford, 1981; 1983). The oral side does exhibit a network of branched channels extending from the margin of the test (ambitus) to the mouth, and serve to transport and feeding purposes (Schrock \& Twenhoefel, 1953; Bell \& Frey, 1969). Other feature include clearly defined petalodium on the apical surface, demiplates in the petaloids, food grooves on the oral surface leading to the mouth, secondary unipores of the ambulacral system, and a highly modified jaw apparatus.

The fossil record shows that irregular echinoids have first appeared during the Jurassic (Sinemurian) and the group quickly evolved and diversified. The clypeasteroids evolved from cassiduloids during the Paleocene and the first true sand dollars appeared during the Eocene. This diversification is attributed to the appearance of morphological adaptations such as flattening and elongation of the test, migration of the anus and development of the petaloids, which allowed these organisms to burrow into the sand and explore new ecological niches. Mellitids evolved from monophorasterids between the Oligocene and early Miocene (Kier, 1982; Smith, 1984).

Irregular echinoids are well represented in the fossil record, due to the fact that they inhabit sandy bottoms that are more favorable to preservation than the rocky bottoms inhabited by regular echinoids, to the burrowing habit, to the interlocking of the plates and to the internal support system that increases the resistance of the test (Kier, 1977; Seilacher, 1979; Donovan, 1991; Kroh \& Nebelsick, 2010). 
The southernmost portion of the Brazilian continental shelf, in the Rio Grande do Sul State is an area rich in fossil remains of Pleistocene organisms (Cunha, 1959; Paula Couto $\&$ Cunha, 1965; Oliveira, 1996). The fossils found on this area include both terrestrial (xenarthrans, meridiungulates, proboscideans, equids, cervids, camelids, carnivores, rodents, reptiles) and marine (mollusks, crustaceans, echinoids, teleost and elasmobranch fish, cetaceans, pinnipeds, aves) taxa (Ribeiro \& Scherer, 2009). These remains are found in biodetrital concentrations along the continental shelf, up to depths of $40 \mathrm{~m}$ and are removed and transported to the beach by winter storms (Figueiredo Jr., 1975; Buchmann, 2002). Although these remains occur all along the $620 \mathrm{~km}$-long coast of Rio Grande do Sul, its distribution is uneven (Buchmann, 1994). The presence of remains of terrestrial organisms in marine environment is attributed to the subaerial exposition of the present continental shelf during sea-level lowstands, related to glacial maxima and its posterior covering by the sea during the interglacial phases (Lopes \& Buchmann, 2010).

Although most of the descriptions of fossil remains from this area have focused on terrestrial vertebrates (e.g. Oliveira, 1996; Scherer, 2005; Hsiou \& Fortier, 2007; Marcon, 2007; Pitana \& Ribeiro, 2007), a few works have described marine taxa (Richter,1987; Buchmann \& Rincón Filho, 1997; Lopes et al., 2006). Regarding the fossil echinoids, there is only a mention of some spines and fragments of the test of Encope emarginata (Leske, 1778) found in transgressive deposits located landwards of the present coastline (Godolphim et al., 1989) and analyses of their distribution along the shoreline (Buchmann, 1994, 1996). The latter author emphasized that none of the fossils could be conclusively attributed to Mellita quinquiesperforata (Leske, 1778), although the existence of such remains was possible.

This presentation contains the first detailed description of echinoid fossils found in the Rio Grande do Sul coast, including observations on its taphonomy and distribution relative to the extant forms found on the same area. The occurrence of fossils of Mellita quinquiesperforata is also confirmed.

\section{GEOLOGICAL SETTING}

The fossils described here were collected along the beach in the southernmost portion of the Brazilian coast. The coastline is part of the Coastal Plain of Rio Grande do Sul State, or CPRS (Figure 1) measuring $618 \mathrm{~km}$ in length with an average width of $100 \mathrm{~km}$, located between the latitudes $29^{\circ} \mathrm{S}$ and $34^{\circ} \mathrm{S}$. It is an open coast, composed mainly by finegrained, well-sorted siliciclastic sands, with higher concentrations of bioclasts, medium-grained sands and heavy minerals in some areas (Villwock \& Tomazelli, 1995; Tomazelli et al., 2000).

The CPRS and adjoining continental shelf constitute the upper portion of the Pelotas Basin, the southernmost marginal sedimentary basin of the Brazilian coast. This basin was formed by the accumulation of terrigenous sediments originated from the erosion of older rocks between the Late
Cretaceous and Cenozoic. The present geomorphology was shaped by eustatic oscillations of the Atlantic Ocean, related to the glacial-interglacial cycles of the Quaternary (Villwock $\&$ Tomazelli, 1995). The most fossil-rich area of the coastline is the $40 \mathrm{~km}$-long sector known as Concheiros, located between 150 and $190 \mathrm{~km}$ to the south of the inlet of the Patos Lagoon. This sector is characterized by coarser sands and a higher slope, along with the presence of large and thick fossil shell concentrations and associated vertebrate fossils. During winter, storm waves remove the remains from the near continental shelf and transport them onto the beach, thus forming the so-called Concheiros.
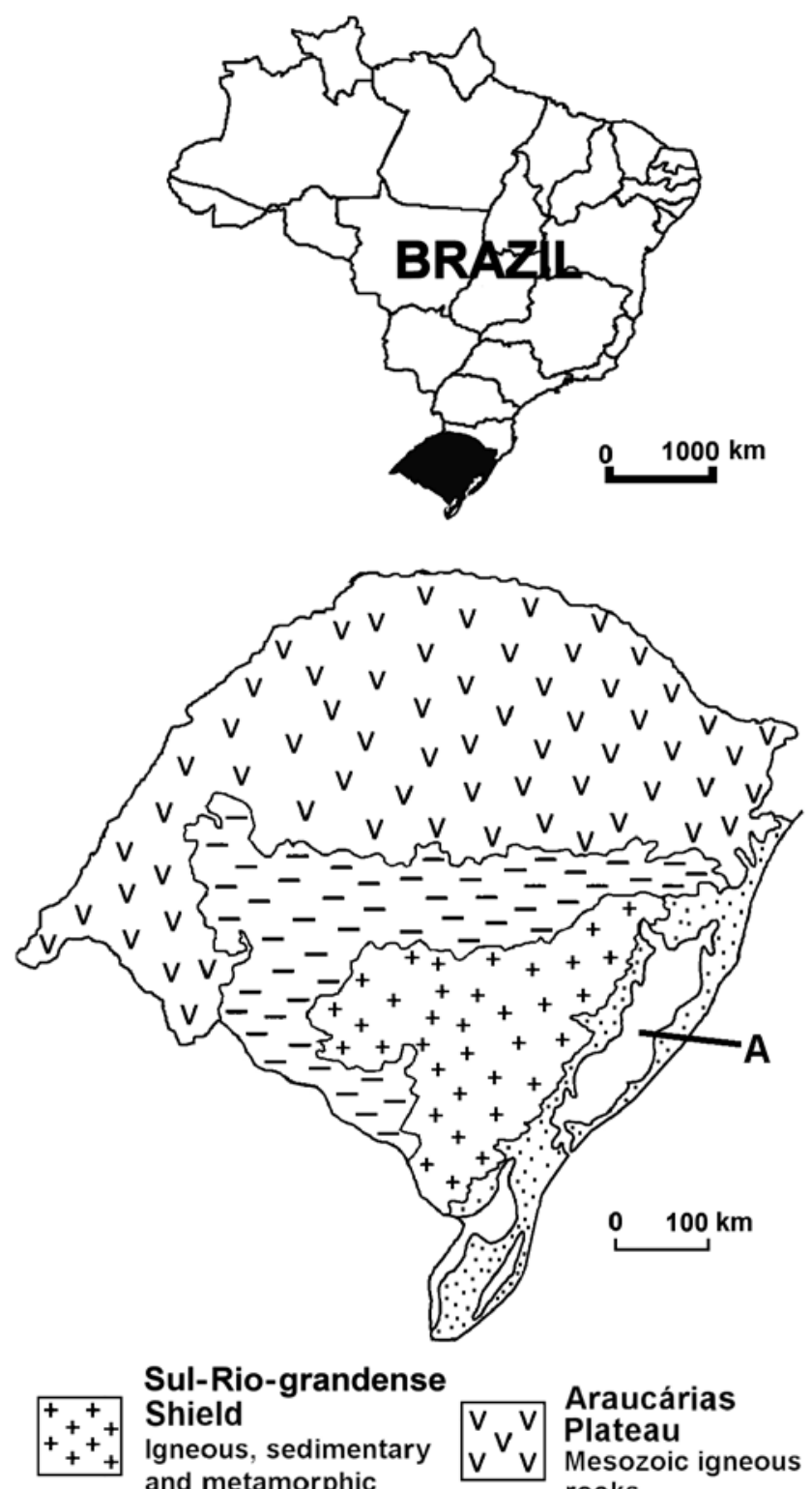

Sul-Rio-grandense Shield Igneous, sedimentary and metamorphic Paleozoic rocks

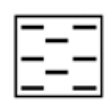

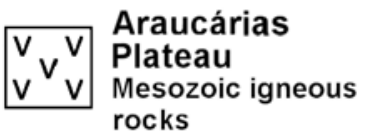
Mesozoic
rocks

Coastal Plain Cenozoic sedimentary deposits

Figure 1. Map of the Rio Grande do Sul State with its major geomorphological units. Abbreviation: A, Patos Lagoon. 


\section{MATERIAL AND METHODS}

Fossils of echinoids can be common along the coast of Rio Grande do Sul, all belonging to irregular forms of the order Clypeasteroida. These remains occur as test fragments along the beach together with molluscan shells and other remains. The fossils described here are stored at the palaeontological collection of the LGP-S/FURG and were collected between 1994 and 2009 during systematic palaeontological surveys along the coastline. For each of the sampling stations, $1 \mathrm{~km}$-long sector of the beach was surveyed for scattered fossils and recent specimens brought to the beach by storm waves. The remains were collected mostly on the southern sector of the coast because most of the collecting efforts have been focused on this area. Nevertheless, Buchmann (1994) demonstrated that the fossil echinoids are more abundant in the areas near to the Sarita, Albardão and Verga lighthouses in the southern sector of the coast. Continuous sampling since then on has demonstrated the consistency of this pattern (Figure 2).
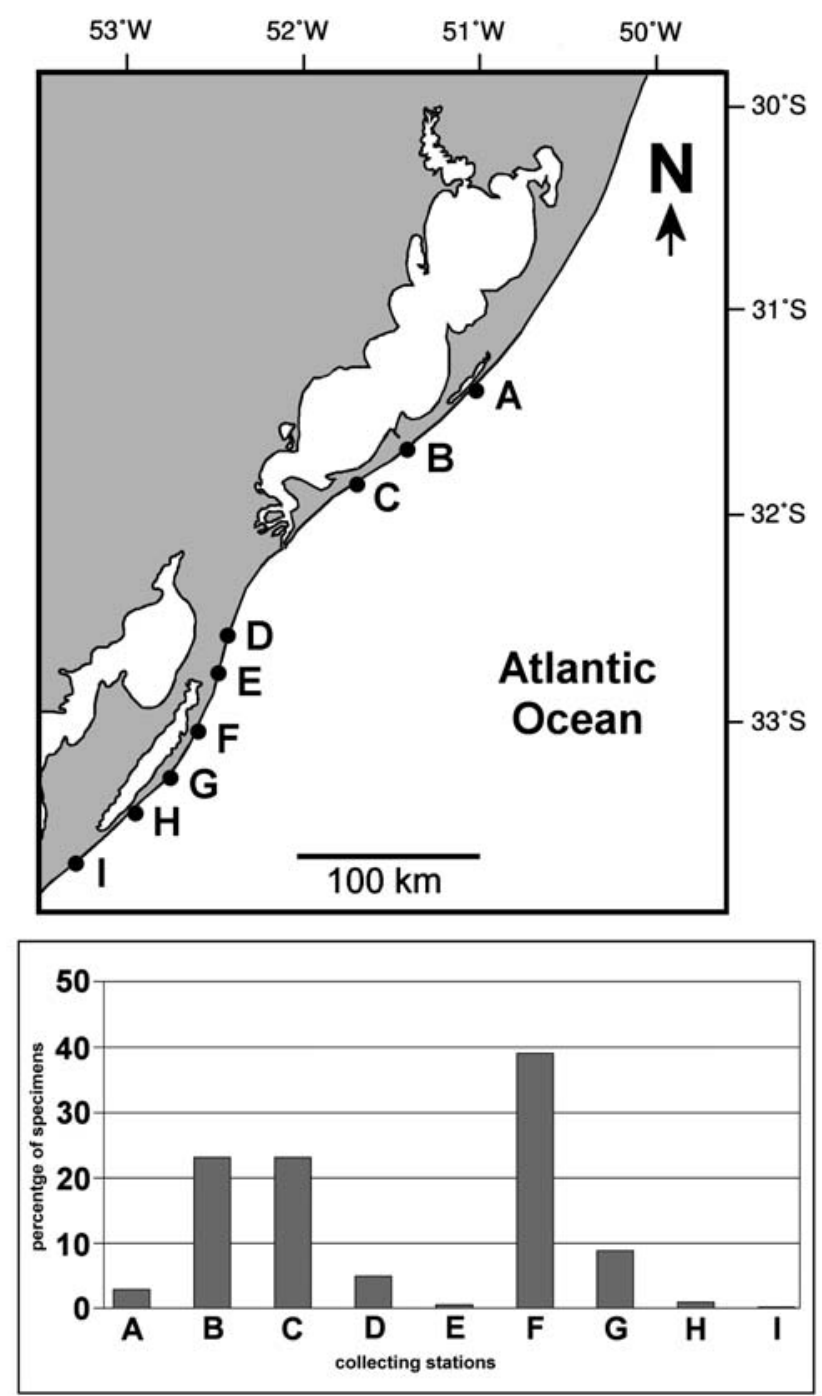

Figure 2. Location of the fossil collecting stations. A, Mostardas; B, Conceição lighthouse; C, Estreito; D, Taim; E, Sarita lighthouse; F, Verga lighthouse; G, Albardão lighthouse; H, Concheiros; I, Hermenegildo.
The present work is based on 584 fossil specimens, all collected on the central and southern portions of the coastline. The fossil specimens are denuded lacking spines. The apical system is also missing. The comparison to Recent specimens is based on features of the tests such as general morphology, presence and position of lunules and food grooves, tuberculation and ambulacral pores.

Abbreviations. CPRS, Planície Costeira do Rio Grande do Sul; LGP-S, Laboratório de Geologia e Paleontologia Echinoidea; FURG, Universidade Federal do Rio Grande.

\section{SYSTEMATIC PALEONTOLOGY}

\author{
Class ECHINOIDEA Leske, 1778 \\ Order CLYPEASTEROIDA Agassiz, 1872 \\ Sub-order SCUTELLINA Haeckel, 1896 \\ Family MELLITIDE Stefanini, 1911 \\ Encope Agassiz, 1840
}

Encope emarginata (Leske, 1778)

(Figure 3A)

Diagnosis. Large, subelliptical to subpentagonal test, truncated and very flattened on the posterior end; domed on the middle-anterior portion. Oral surface plain or slightly concave. Subelliptical lunules, four ambulacral and one interambulacral (anal); the latter is longer than the ambulacral ones and corresponds to $\sim 21 \%$ of the length of the test. Posterior petaloids larger than the anterior ones. Five genital pores, interambulacral median spaces covered by large tubercles; depressed ambulacral area between food grooves (Agassiz, 1841, 1872; Phelan, 1972).

\section{Mellita Agassiz, 1841}

Mellita quinquiesperforata (Leske, 1778)

(Figure 3B)

Diagnosis. Very flattened, discoidal test, 9 to $29 \%$ wider than long; widest at the posterior interambulacral space. Aboral side domed on the middle-anterior portion, oral surface plain or sligthly concave. Four ambulacral and one anal lunule, all long and narrow; anterior lunule (III) absent. Posterior petaloids slightly longer; four genital pores (Agassis, 1872; Clark, 1940).

\section{Discussion on the two above species}

The members of the family Mellitidae are characterized by the flattened test with well-defined petaloids, small basicoronal plates, a large anal lunule, channels that enter the anal lunule, a special channel that serves as a passage to the first section of the intestine, and periproct positioned near or on the edge of the first pair of basicoronal plates (Durham, 1966; Harold \& Telford, 1990).

Mellita quinquiesperforata does not exceed lengths of $100 \mathrm{~mm}$ (Harold \& Telford, 1990) while Encope emarginata reaches some $130 \mathrm{~mm}$ in length. The Recent specimens of the former collected in the study area do not exceed $55 \mathrm{~mm}$ in 
length, possibly representing juvenile individuals living near the beaches, or the prevailing environmental conditions don't allow this taxon to reach larger sizes. Another feature distinguishing the taxa is the number of lunules: E. emarginata possesses six lunules (five ambulacral and one anal) while $M$. quinquiesperforata has five lunules lacking the ambulacral lunule III (located on the anterior end of the test). In the latter, the ambulacral lunules are long and closed, never extending to the ambitus, while E. emarginata exhibits a large variations in shape and dimensions of the lunules as, for example, the ambulacral lunules can be either closed or open.

Both Mellita quinquiesperforata and Encope emarginata are the only living echinoids recorded so far along the coast of Rio Grande do Sul. Of these, only E. emarginata has been found south of the La Plata river (Ghiold, 1989; Martínez \& Mooi, 2005). On the coast of Rio Grande do Sul, $M$. quinquiesperforata is found inhabiting areas ranging from the surf zone up to depths of $10 \mathrm{~m}$ (Gianuca, 1998). E. emarginata inhabits sediments between depths of 15 and 40 $\mathrm{m}$ (Capitoli, 1998). Both taxa are restricted to fine to very finegrained sands, although specimens around the Patos Lagoon inlet are subject to occasional covering by mud (Borzone \& Griep, 1991; Calliari \& Facchin, 1993). In the area of the
Concheiros, where the substrate is composed by mediumsized sand and shell fragments, there is no record of living specimens of $M$. quinquiesperforata or E. emarginata (Barros et al., 1994). Although M. quinquiesperforata lives all along the coast of Rio Grande do Sul, it is more conspicuous in the northern portion of the coast, where large concentrations are sometimes formed along the beach in response to changes in the wave regime, related to meteorological conditions (Neves \& Bemvenuti, 2009). As yet, there are no detailed studies regarding the distribution of E. emarginata along the coast of Rio Grande do Sul.

\section{RESULTS}

\section{On the morphology and description of the specimens}

Taxonomic identification of the fossils was difficult because of their fragmentary condition. Differentiation is based on the morphology of the test and/or shape of the lunules, when these were present. Only 133 specimens were identified as Encope emarginata, while only two, numbered LGP-S0435 and LGP-S0436, were positively recognized as Mellita quinquiesperforata, both identified by the absence of the lunule III only (Figure 4).
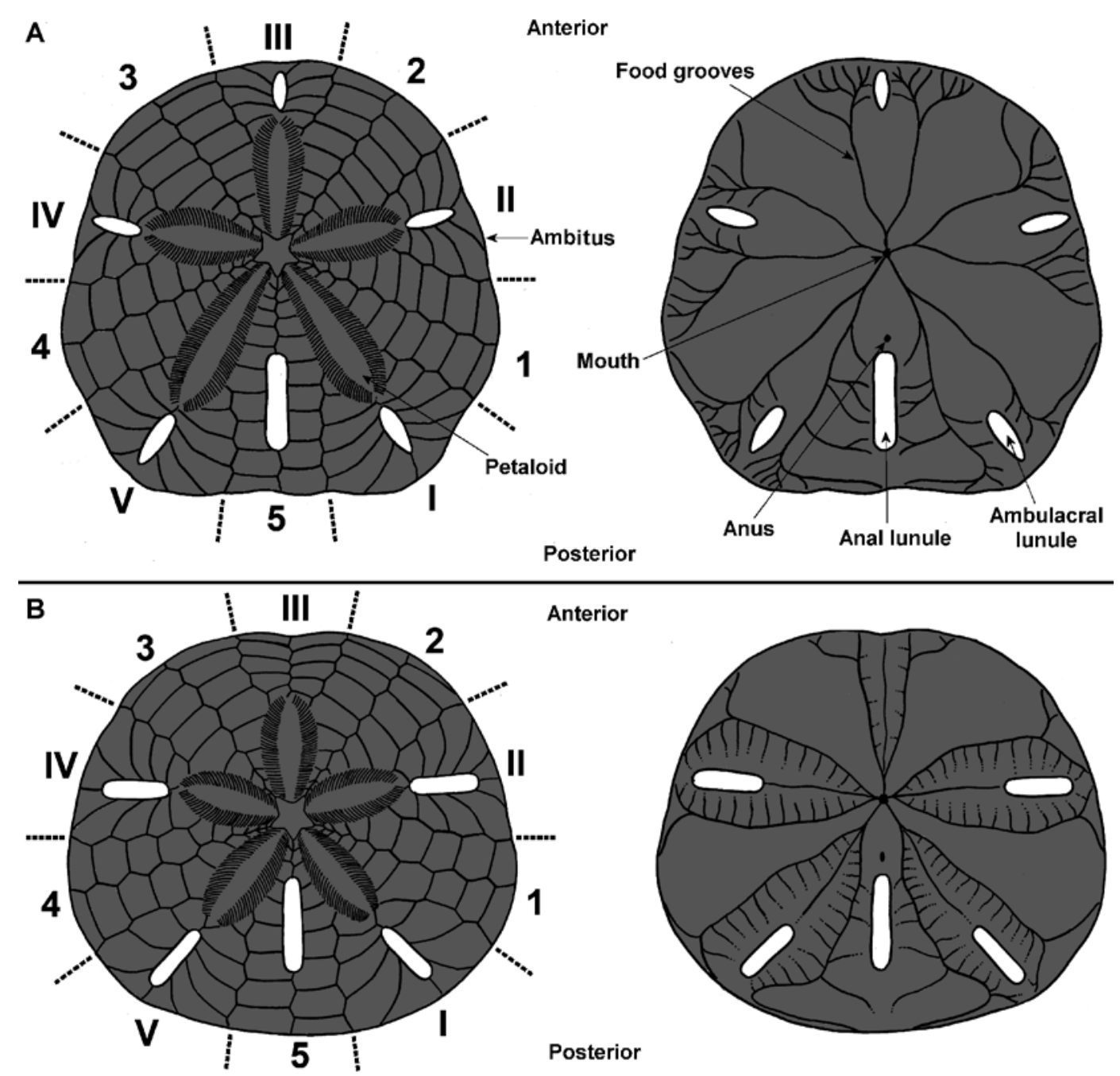

Figure 3. External morphology of the test of Encope emarginata (A) and Mellita quinquiesperforata (B), in aboral (left) and oral views. The ambulacral areas are indicated by Roman and the interambulacral by Arabic numbers. Not drawn to the same scale. 
All specimens are fragments that exhibit varying degrees of preservation, and were measured for maximum thickness, radius (distance measured from the apical portion to the ambitus) and length (measured at the ambitus, perpendicular to the diameter). The radius of the specimens varies between 16 and $66.5 \mathrm{~mm}$ (mean radius of $35.6 \mathrm{~mm}$ ), the length varies between 6.5 and $92 \mathrm{~mm}$ (mean length of $39.5 \mathrm{~mm}$ ), and between 3.5 and $15.5 \mathrm{~mm}$ in thickness (mean thickness of $8.8 \mathrm{~mm}$ ).

On most of the fossils, the apical portion of the test is not preserved. The only exception to this pattern is seen on the specimen LGP-S0453, which has the madreporite and most of the Aristotle's lantern preserved (Figure 5); this specimen also exhibit evidence of crushing. The most complete specimens represent some $30 \%$ of test area. Most of the specimens are subtriangular-shaped fragments wider and thinner at the ambitus, becoming narrower and thicker towards the apical portion. This is due to the fact that disarticulation occurred preferentially along the radial sutures, between the ambulacra and interambulacra. A few specimens show fragmentation along the interplate sutures.

On 332 specimens it was possible to identify to which sector of the test the fragment belongs. This identification was possible because of the morphological differences between each sector: the anterior portion is more domed, while the posterior is more flattened and straight at the ambitus. There is a marked angle between the posterior and lateral margins of the test in Encope emarginata and posterior petaloids (I and IV) much longer than the anterior ones. The majority (69\% of the specimens) represent the posterior half of the animal, mostly corresponding to the sector V-5-I of the test, while very few specimens represent the anterior half (Figure 6).

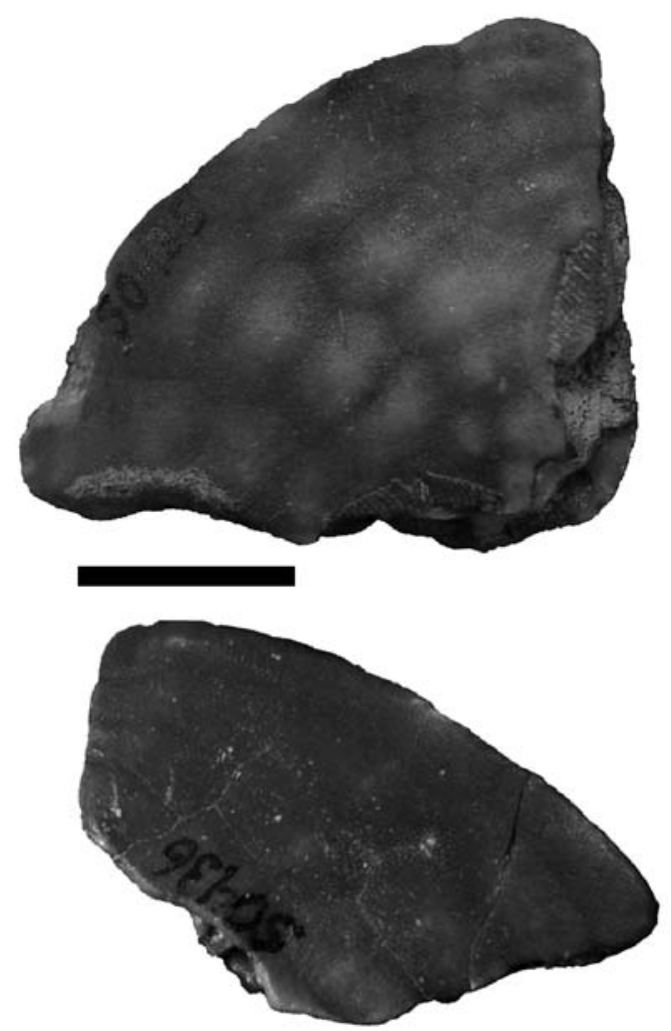

Figure 4. The two specimens identified as Mellita quinquiesperforata, LGP-S0435 (on top) and LGP-S0436 (bottom). Scale bar $=10 \mathrm{~mm}$.
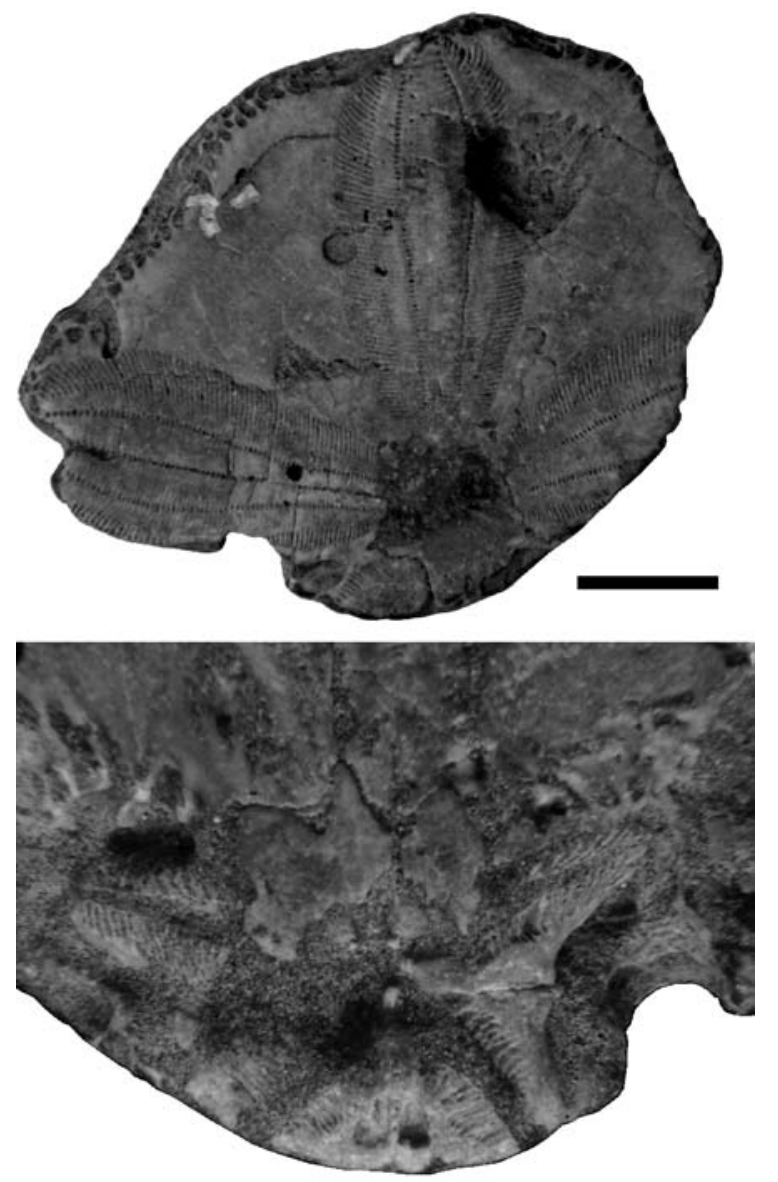

Figure 5. Encope emarginata (LGP-S0435), showing the preserved madreporite (top) and detail of the Aristotle's lantern elements (bottom). Scale bar $=10 \mathrm{~mm}$.

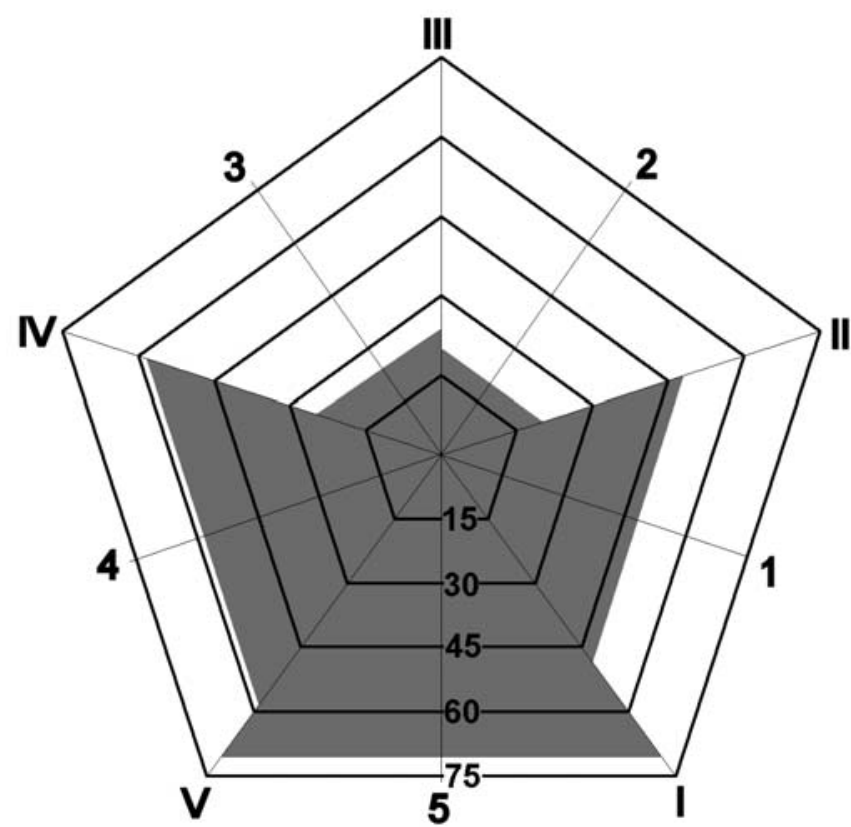

Figure 6. Schematic drawing of the test of Encope emarginata, with shaded areas representing the relative percentages of specimens corresponding to each sector. 
On 32 specimens, at least one lunule is well preserved. On these specimens, the lunules exhibit morphological variations in shape and length/width proportion, besides being closed or opened at the ambitus (Figure 7A). On 198 specimens, one or more petaloids are present. Only 40 petaloids are intact, the remaining 211 are total or partially damaged. On the latter, the lateral portions that correspond to the respiratory orifices are collapsed, while the central portion remains present (Figure 7B). The highest proportion of intact petaloids ( $85 \%$ ) is found on specimens with internal cavities filled by lithified sediments (see below), that could prevent collapse. Nevertheless, 62 (29.4\%) collapsed petaloids are found on specimens with open internal tests, 41 (19.4\%) on specimens partially filled with sediment and $108(51.2 \%)$ on specimens with completely filled internal cavities, suggesting that the infilling occurred after collapse of the specimens. The fossils exhibit color variations, ranging from white (17 specimens), to black (41 specimens), brown (115 specimens) and gray (410 specimens).

Most of the fossils (580 specimens) exhibit signs of abrasion, classified as slightly abraded (219 specimens) to highly abraded (361 specimens). Slightly abraded fossils are characterized by rounded edges and discernible individual plates. On specimens classified as highly abraded, most of the external surface of the test has been removed, exposing the internal features of the ambulacral system. Despite the abrasion, seven specimens exhibit well-preserved tubercles on oral and/or aboral surfaces (Figure 7C). The only unabraded specimens are the two identified as Mellita quinquiesperforata plus other two unidentified fragments. On $72.8 \%$ of the fossils a high degree of abrasion is visible on both oral and aboral surfaces, while on $0.7 \%$ abrasion is
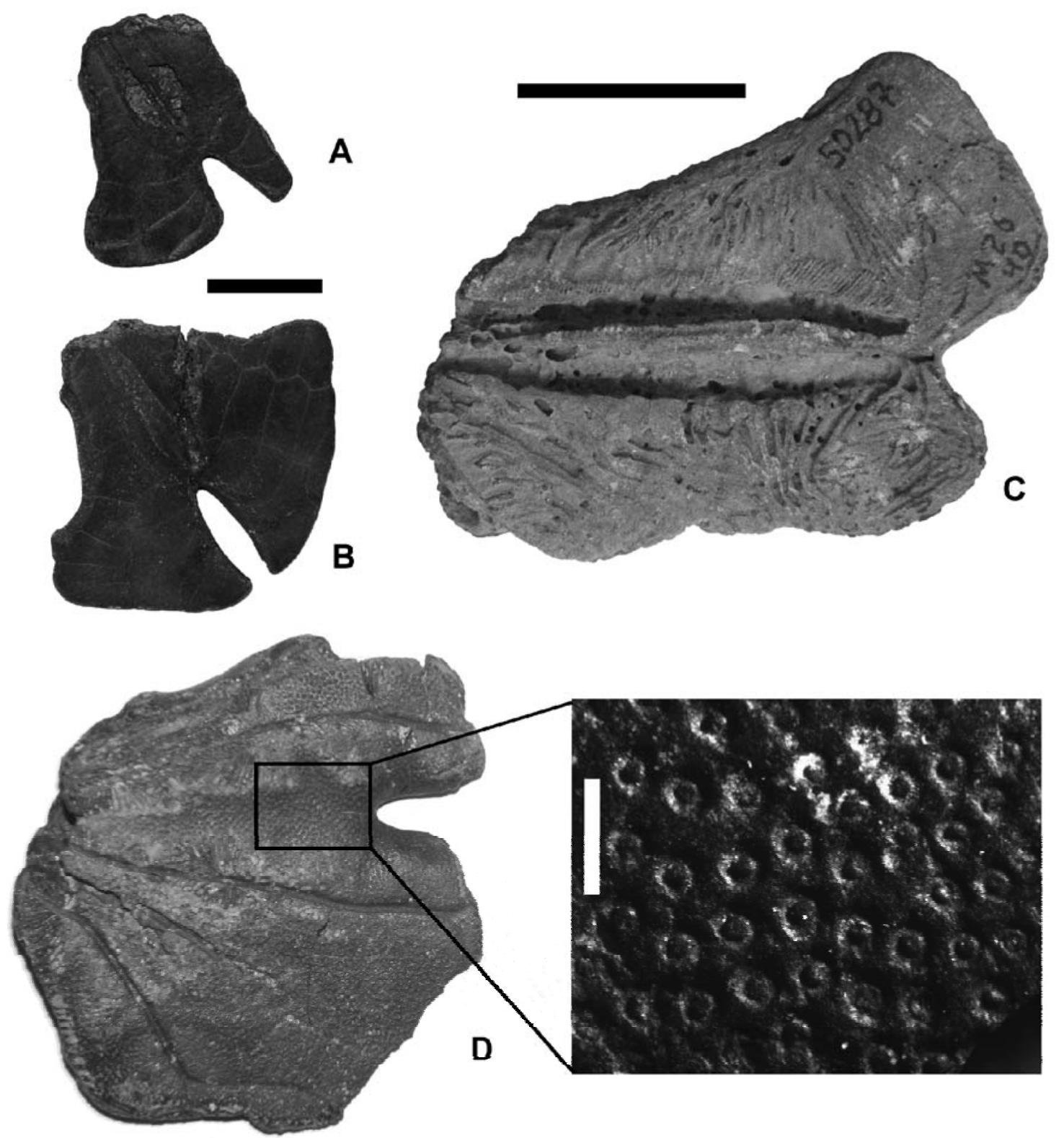

Figure 7. Encope emarginata. A, B, LGP-S0430 (A) and LGP-S0148 (B) showing variations on morphology of the lunules; C, LGP-S0288 with a collapsed lunule; D, LGP-S0080, well-preserved tubercles on the oral surface. Scale bars: A-C = $10 \mathrm{~mm}$; $D=1 \mathrm{~mm}$. 
visible only on the aboral surface and on $26.4 \%$ it is visible only on the oral surface (Figure 8A).

On 384 specimens, the internal cavities are total or partially filled with lithified sediments, either very fine sand or mud (Figure 8B), and on a few specimens the recrystallization and expansion of the carbonate cement inside the cavities have caused the specimens to appear "swollen". Eighty five specimens show an external covering by indurated sandstone, while 19 others are covered by sand or mud and shell fragments all cemented together, forming coquinas (Figure 8C). Sixty three specimens are internal molds of the animals, constituted by mud that filled the internal channel network and digestive tract. These specimens show no signs of the original test, although the lithified muddy infilling have preserved anatomic details (Figure 8D). Some of these molds exhibit a secondary infilling of cavities by lightly-colored sediment.
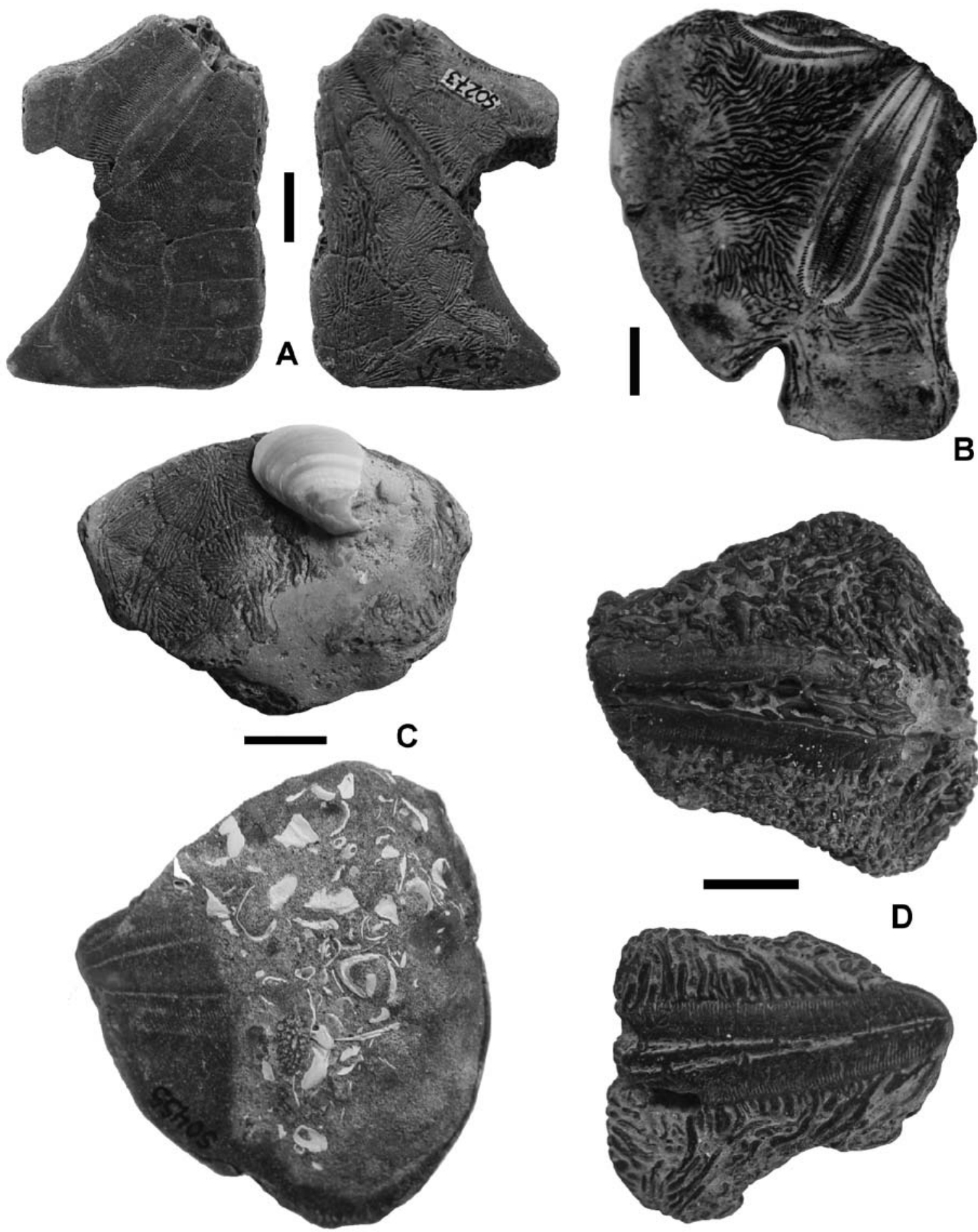

Figure 8. Encope emarginata. A, LGP-S0273 showing differential abrasion on oral and aboral surfaces; B, LGP-S0461, internal channel network filled with dark mud and exposed due to abrasion; C, LGP-S0455 and unnumbered specimen with coquinas; D, LGP-S0349 (top) and LGP-S0386 (bottom), internal casts formed by mud that filled the internal cavities of the original echinoid. Scale bars $=10 \mathrm{~mm}$. 
Only six specimens exhibit encrustation by episkeletozoan organisms (sensu Taylor \& Wilson, 2002). Two are encrusted by ostreid bivalves and one of these was colonized by an Ostrea puelchana that grew larger than the echinoid specimen itself (Figure 9A). Two other specimens were colonized by cirripeds (Figure 9B). Two other specimens show deep ovoid borings made probably by endoskeletozoan organisms; one of these still have a Litophaga mussel preserved inside the chamber (Figure 9C). The only signs that may possible be related to predation by gastropods are small circular holes in the aboral surface of the specimen LGP-S0453.

\section{Comparison with Recent specimens}

According to Nebelsick (1999), the presence of echinoids in the fossil record is related to skeletal morphology, environmental conditions and temporal effects. By using actualistic studies on Recent taxa, it is possible to evaluate how these factors affect its preservation. Identification of biostratinomic processes such as transport, disarticulation abrasion and encrustation on Recent specimens can be recorded in extent specimens and then extrapolated to fossil samples (Nebelsick, 1995, 2008; Kroh \& Nebelsick, 2010). Following this rationale, a comparison between fossil and Recent echinoids was also performed in order to assess taphonomic features and correlate the distribution of the organisms to environmental parameters.

Recent specimens used for comparison consist of 24 Mellita quinquiesperforata and 128 Encope emarginata, all collected along the beach together with fossils during the last two years. Four complete, living specimens of the latter were collected at greater depths on the continental shelf, during oceanographic surveys with the research vessel 'Atlântico Sul'. Specimens of $M$. quinquiesperforata are all complete, unabraded tests that exhibit the original color, sometimes with the spines still attached. These specimens measure no more than $55 \mathrm{~mm}$ in length (mean $=47 \mathrm{~mm}$ ) and $64 \mathrm{~mm}$ in diameter $($ mean $=52.5 \mathrm{~mm})$. The specimens were not collected at the same place and time, thus did not form large concentrations that would indicate a mass mortality event. None of these remains exhibit signs of encrustation by epi- and/ or endoskeletozoans, and no small fragments that could be identified as $M$. quinquiesperforata were found on the beach.

Scattered Recent remains of Encope emarginata are also found along the beach, but are more common than Mellita quinquiesperforata. Although in general these specimens are better preserved than the fossils, all are spineless, white fragments very similar to the fossils of E. emarginata. They are more fragile in comparison to the fossils, and on average have larger dimensions than the fossil specimens, measuring
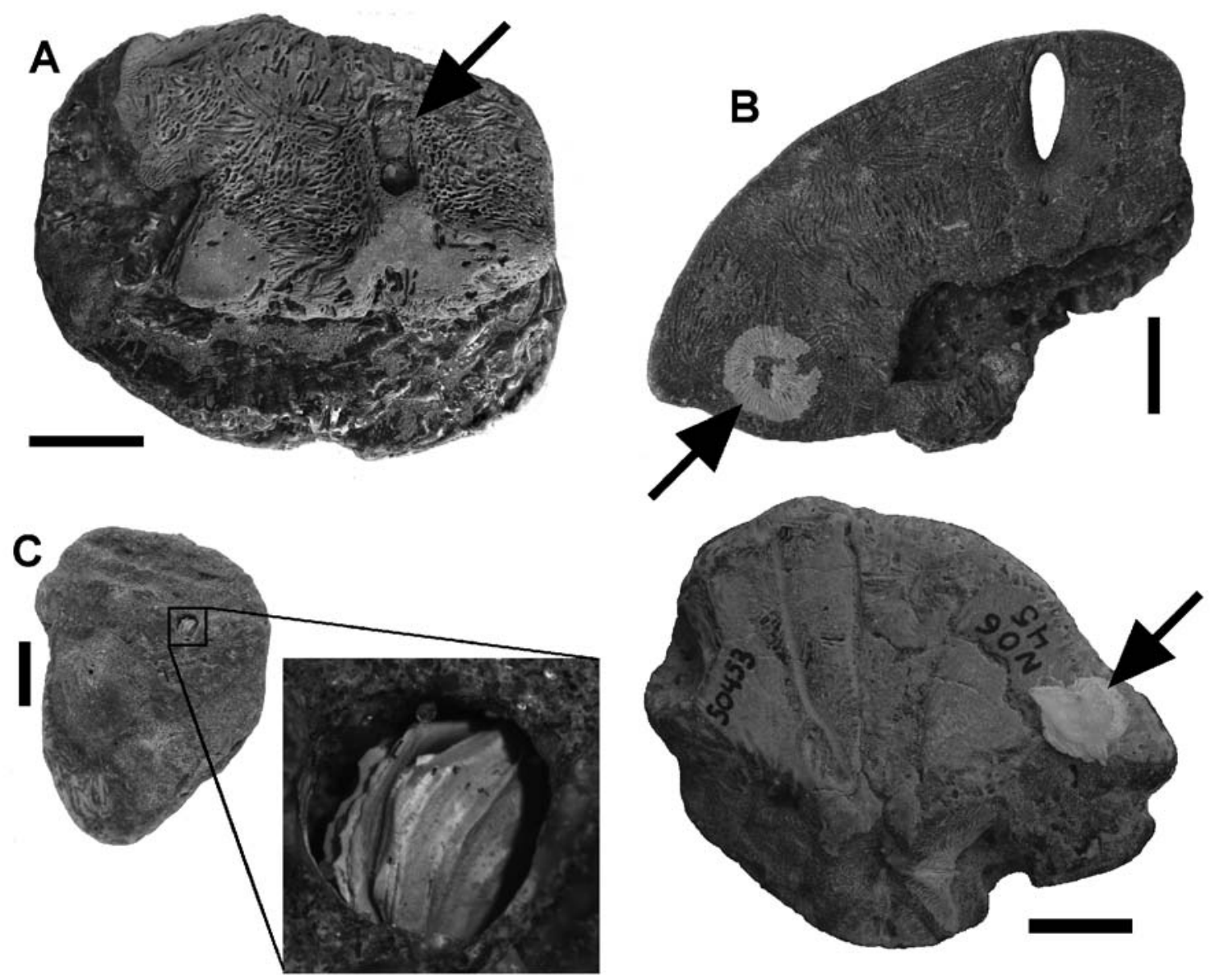

Figure 9. Examples of encrustation by marine organisms in Encope emarginata. A, an encrusting Ostrea puelchana on LGP-S0454, the anal lunule is indicated by arrow; B, LGP-S0152 (top) and LGP-S0453 (bottom), showing encrustation by cirripeds (indicated by arrows) on its oral surfaces; C, LGP-S0569 bored by a Litophaga sp., still preserved inside the chamber. Scale bars $=10 \mathrm{~mm}$. 
between 20 and $118 \mathrm{~mm}$ in radius (mean $=50.2 \mathrm{~mm}$ ), between 24 and $157 \mathrm{~mm}$ in length ( mean $=55.4 \mathrm{~mm}$ ) and between 6.5 and $18 \mathrm{~mm}$ in thickness (mean $=12 \mathrm{~mm}$ ). The pattern of fragmentation along the interplate sutures is the same observed on the fossil samples, and the fragments are mostly subtriangular-shaped, representing small portions of the test. Remarkable exceptions to this pattern are two specimens that correspond to some $50 \%$ of the test, and even have the apical portion preserved (Figure 10).

On 108 specimens, at least one petaloid is visible, making a total of 168 petaloids. Of these, $70 \%$ are total or partially
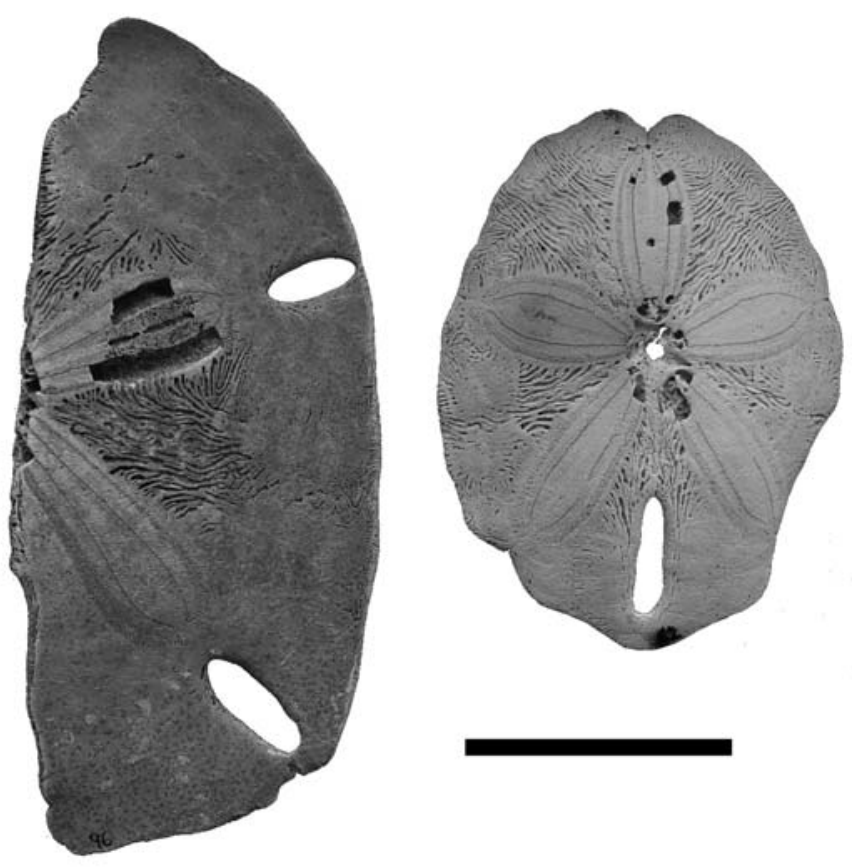

Figure 10. Well-preserved Recent specimens of Encope emarginata. Scale bar $=50 \mathrm{~mm}$. collapsed, while $30 \%$ are intact. All specimens exhibit signs of abrasion; $31.4 \%$ were classified as lightly abraded and $68.6 \%$ as very abraded. On $75.5 \%$ of the specimens a high degree of abrasion is observed on both oral and aboral surfaces, while $24.5 \%$ exhibit abrasion only on the oral surface. No specimen presents abrasion only on the aboral surface, traces of encrustation or lithified sediment and coquinas, either internally or externally. Of the 112 specimens that could be identified regarding its position within the test, $66 \%$ correspond to the posterior portion, between interambulacra 4 and 1 ; and $34 \%$ correspond to the anterior portion, between ambulacra II and IV. On 32 specimens there is at least one ambulacral lunule preserved, and these exhibit the same morphological variation found on fossil Encope emarginata.

Comparison of biostratinomic features found on fossil and Recent specimens of Encope emarginata, plotted on graphs, show several similarities (Figure 11). For this comparison, abrasion was classified as absent (0), little (1) or high (2); internal cavities were classified as open (0), partially filled with sediment (1) or completely filled (2); petaloids were classified either as intact (0) or collapsed (1), and the relative proportion of specimens corresponding to the anterior or posterior portion of the test was also plotted. The pattern of abrasion is similar on both fossil and Recent specimens, although on the latter the proportion of highly abraded specimens is higher. On Recent specimens the cavities are all open, because today there are no environmental conditions for the precipitation of carbonate cements. The proportion between intact and collapsed petaloids is similar on both fossil and Recent E. emarginata, although on the latter the proportion of collapsed petaloids is higher, possibly because of the absence of lithified sediments on the internal cavities. The relative proportion of specimens that correspond to the anterior half of the test is slightly higher on Recent specimens.

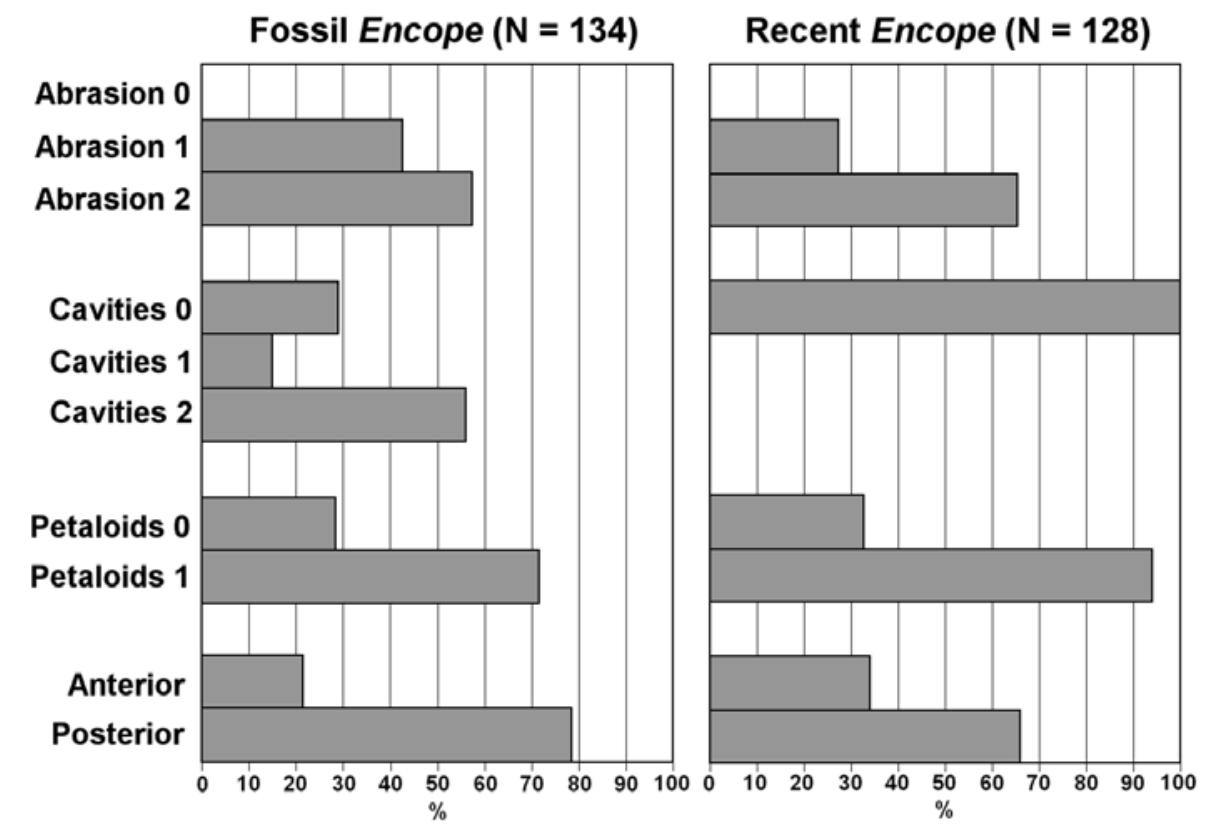

Figure 11. Comparison of biostratinomic features on both fossil and Recent Encope emarginata from the southernmost Brazilian coast. 


\section{DISCUSSION}

The low proportion of fossils of echinoids on the portion of the CPRS between the Albardão lighthouse and Chuí is probably a result of the large concentration of biodetritus found in this area. Because both Mellita quinquiesperforata and Encope emarginata have smaller and more numerous tube feet in comparison to other irregular echinoids, adapted to feed in mud/fine sand substrates (Smith, 1980; Telford \& Mooi, 1986), these taxa would not be able to obtain food among shell fragments and coarser sand. The same distribution pattern is found among Recent specimens, which suggests that the paleoenvironment in which the remains were preserved was much similar to that of the present distribution of these taxa. Without absolute datings of the specimens, it is difficult to estimate an age for these remains, because the area was subject to at least four major cycles of sea-level transgression and regression, which eroded and reworked older deposits, mixing together fossils of different ages (Lopes et al., 2010). Nevertheless, it can be estimated that the best preserved remains were not subject to much reworking, they thus might be of latest Pleistocene to earliest Holocene in age. Fossils with external carbonate cement, forming beachrocks or coquinas, can be assigned at least to this time interval, because the climatic conditions that allowed the precipitation of the carbonate, such as interstitial water with temperatures above $20^{\circ}$ during half of the year in the intertidal zone (Russell \& McIntire, 1965; Cooper, 1991) were present only during the early phases of the Holocene transgression, around $7 \mathrm{ka} \mathrm{BP}$ or during one of the Pleistocene marine oscillations. Fossils that contain only internal cavities filled with lithified sediment may be produced by the diagenetic processes affecting the ossicles, because after decomposition of the soft parts and the following transition from marine to meteoric freshwater, calcite cement starts to form and can promote lithification and infilling of the stereom and larger internal cavities by calcite crystal growth (Nebelsick, 2004; Kroh \& Nebelsick, 2010), which can also bond sand or mud grains together.

The larger proportion of fossils of Encope emarginata is probably a result of two main factors: the smaller size of Mellita quinquiesperforata, which would make it more prone to breaking due to wave action in the surf zone, and the migration of the habitats in response to sea-level oscillations. Sea-level curves for the Brazilian coast show that after the last glacial maximum around $20 \mathrm{ka} \mathrm{BP}$, there was a continuous rise until 7 $\mathrm{ka} \mathrm{BP}$, when it reached the present level; it continued to rise, reaching about $2.1 \mathrm{~m}$ above the present level at $5.1 \mathrm{ka} \mathrm{BP}$ and then started to fall slowly until today (Angulo et al., 2006). During a marine transgression (transgressive systems tract), the rising sea would cause erosion of the shoreline, accumulating coarser sediments (including fossils) in the wave ravinement surface, thus forming lag deposits, and would transfer finer sediments to the offshore (Assine \& Perinotto, 2001). Thus, during the sea-level highstand (highstand systems tract) around $5.1 \mathrm{ka} \mathrm{BP}$, the shallower zone inhabited by $M$. quinquiesperforata would have been located landwards of the present coastline. The deeper zone inhabited by E. emarginata would also have been located nearer the present coastline during the highstand. Under a scenario of sea-level rise and the following sea-level highstand, with the maximum depth range of waves migrating landwards, many dead tests of the latter would slowly accumulate, be buried and remain undisturbed at greater depths. During the following marine regression, the fossils preserved in the upper sedimentary layers nearer the coastline would be exposed to intertidal environments, which would provide conditions for the formation of beach rock around these remains. Those preserved in the lower portions of the sequence can remain undisturbed until being eroded by subsequent processes. In the CPRS, the sea-level regression of the last 5.1 thousand years has been followed by erosion of the coastline and near continental shelf due to negative sediment budget (Dillenburg et al., 2004); this erosion seems to be the main responsible for reworking of the fossils accumulated in the lag deposits during the preceding transgressive phase.

The zone inhabited by Encope emarginata today remains below the action of normal wave regime, thus this taxon is disturbed only during extreme storm events. The continental shelf in the study area has a low slope, so the distance between the living zone of E. emarginata and the beach is of several kilometers, indicating that the remains of dead individuals are subject to biostratinomic processes in the taphonomic active zone (TAZ) for a considerable time interval until reaching the beach. Because Recent tests of this taxon are more fragile than their fossil counterparts, no complete Recent specimens can withstand transportation for such long distances without breaking and becoming abraded.

Mellita quinquiesperforata lives at depths that are constantly subject to wave action and nearer the beach, and because of that, one could presume that dead tests remain for a shorter period of time in the TAZ and would expect to find more recent specimens of this taxon. The relative absence and the occurrence of only complete, small individuals of this taxon may indicate that these are juveniles, while larger (adult) individuals live in deeper areas relative to the young ones, thus would be destroyed before reaching the beach. It is not clear yet if the smaller tests found on the beach really represent juveniles or if there are ecological factors that do not allow this taxon to reach larger sizes. The tests of small individuals found on the beach are probably individuals that died recently, and would soon be completely destroyed if have not been collected. The fragility of the test of $M$. quinquiesperforata in comparison o the much larger and robust Encope emarginata is another factor that contributes to the scarcity of the former as fossils in the study area. Nevertheless, one can not exclude the possibility that several unidentified fragments may represent $M$. quinquiesperforata, but do not exhibit any diagnostic features. A survey of smaller particles found on the beach using sieves failed to reveal any smaller fragment or isolated plates of echinoids, either Recent or fossil.

Internally, the clypeasteroid test is supported by a meshwork of columns, connecting the aboral and oral surfaces 
(Seilacher, 1979). The low proportion of specimens of Encope emarginata representing the anterior and apical portions of the test is probably due to the presence of the large cavity for the digestive tract, which makes it more prone to fragmentation. On the other hand, the predominance of specimens representing the posterior portion is related to the compact, flattened shape of this part of the test, which makes it more resistant to fragmentation.

There are no conclusive evidences of mass mortality events among fossil echinoids from southern Brazil. If such events happened, its records would probably have been obliterated by large scale sea-level oscillations. On the other hand, no large concentrations of dead echinoids have been observed today. The main causes of such events are desiccation during the low tide, decrease in oxygen levels, high salinity or burial during storm events or obrution (Schäfer, 1972; Smith, 1984; Nebelsick \& Kroh, 2002; Nebelsick, 2004). In the southern Brazilian coast, which is subject only to microtidal regime and is well oxygenated due to constant water movement by longshore currents, burial during storms would be the most likely agent of mass mortality. Another possible agent would be a drop in salinity; Bell \& Frey (1969) observed that Mellita quinquiesperforata can not survive for long under salinity below $18 \%$, and seems best adapted to salinities of $23 \%$ and higher. In the study area the only source of freshwater discharges on the beach are small, ephemeral streams that flow from wetlands on the backbarrier and cross through the front dunes during rainy epochs. No relationship, however, between the presence of dead M. quinquiesperforata and these streams was observed.

The morphological variations observed in the lunules of the fossil Encope emarginata allowed the recognition of five morphotypes (Figure 12), which show relation to its position on the test. Type I lunules are the only closed at the ambitus, and are found on specimens corresponding to both anterior and posterior portions of the test; type II are mostly anterior (six specimens), while types III, IV and V occur mostly on the posterior portion (seven, six and 20 specimens, respectively). Because no correlation between the morphotypes and size of the specimens was observed, it is not clear whether these variations can be related to ontogenetic development. The lunules in E. emarginata are formed by notches on the ambitus of the test of juvenile individuals that progressively became totally or almost totally closed in the adult phase (Agassiz, 1872). Morphological variations on the lunules are observed on living individuals of E. emarginata collected along the eastern South American coast, but it's not clear whether are just intraspecific variations or represent the existence of distinct subspecies (Hopkins \& Ventura, 2000).

Evidences of predation such as borings and bite marks along the ambitus, attributed to cassid gastropod and fish, respectively (Zinsmeister, 1980; Kier, 1981; Gibson \& Watson, 1989; Nebelsick \& Kowalewski, 1999), have not been observed. Evidences of encrustation by epizoans are present, but very scarce. In a coastal areas composed by unconsolidated fine sediments, such as in southernmost Brazil, biogenic hard parts (shells, carapaces, tests, bones) of dead organisms constitute the only hard substrate available to encrustation by both epizoans- and/or boring organisms, and can thus be quickly colonized after death (Nebelsick $e t$ $a l .$, 1997). The relative absence of traces of encrustation both on Recent and fossil echinoid remains may indicate that the remains were covered by sediment prior to its removal and transportation to the beach. In contrast, most shells of dead mollusks found in the area, either fossil or Recent, exhibit borings caused by clionid sponges, polychaetes and bryozoans (Lopes \& Buchmann, 2008). This might indicate that either the shells remain exposed for a longer time in the water/sediment interface, or that the test of echinoids is not suitable for perforation by such organisms. The absence of encrustation and borings may also be related to the mode of

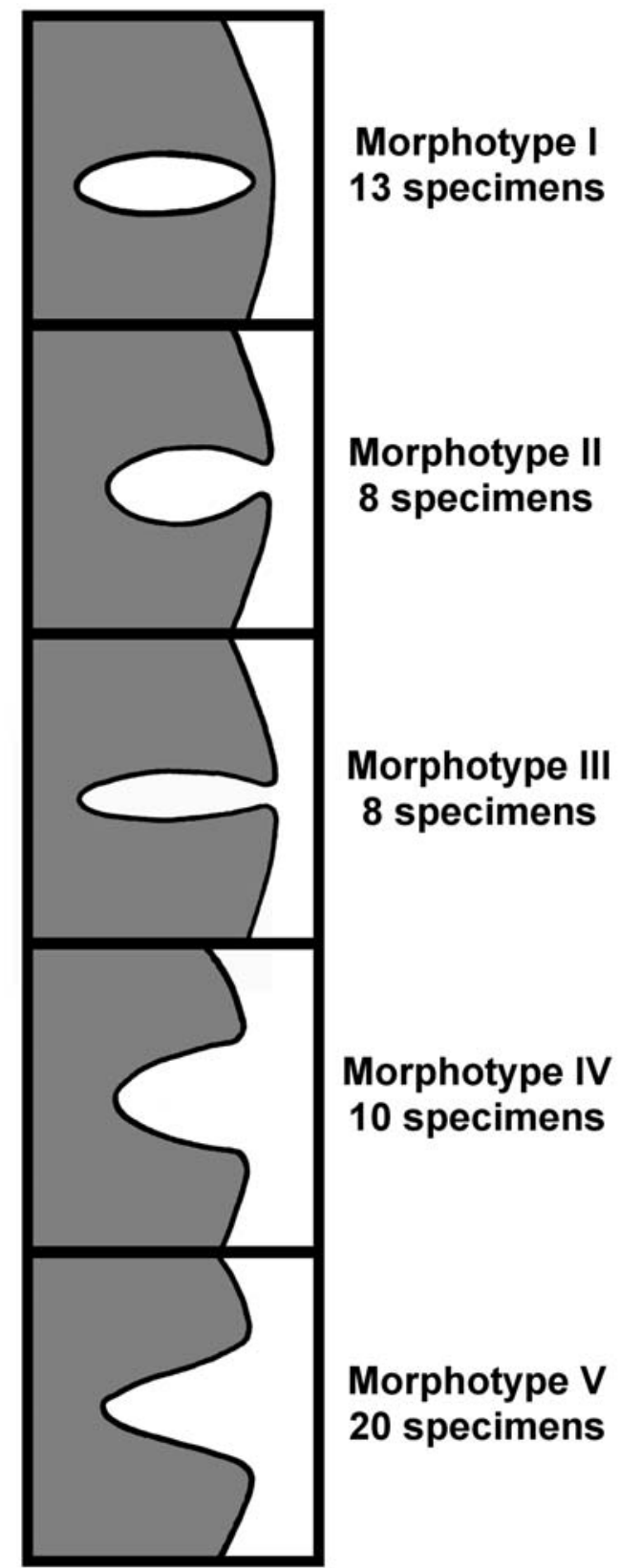

Figure 12. Morphotypes of lunules found on both fossil and Recent Encope emarginata. 
death, if these organisms died because of burial by sediments during storm events. According to Schäfer (1972), a $30 \mathrm{~cm}$ thick sediment covering can kill clypeasteroids, which are adapted to shallow burial. No specimen (save for the LGP-S0453) exhibits signs that could be related to implosion of the central portion of the test due to sediment overload, thus indicating that the specimens were never deeply buried.

\section{CONCLUSIONS}

Fossils of irregular echinoids from the southernmost Brazilian coast are represented mostly by Encope emarginata; although remains of Mellita quinquiesperforata have also been recorded, these are much scarcer in comparison. Fossil specimens of $E$. emarginata exhibit a similar preservation to Recent specimens, except for diagenetic features such as lithification of infilling or surrounding sediment. This indicates that most of the taphonomic features observed in the fossils may be caused by pre-burial biostratinomic processes such as transport and related fragmentation and abrasion. Nevertheless, one cannot discard the possibility that dead remains, that were buried and fossilized intact at greater depths under a transgressive sea-level regime, may have acquired its biostratinomic features as a result of postburial reworking and transportation during a following sea-level fall. The analysis of biostratinomic features on both fossil and Recent specimens of E. emarginata suggests two possible taphonomic scenarios: (i) recently dead tests are removed by waves, becoming fragmented and abraded before final burial and diagenesis; or (ii) dead individuals are covered by sediment, its remains are subject to diagenesis and then removed by erosion, becoming fragmented and abraded in the process. The biostratinomic similarity between fossil and Recent specimens indicates that the first scenario is the most likely.

The scarcity of fossil specimens and the occurrence of only living, recently dead and complete individuals of Mellita quinquiesperforata, do not allow for a comparison of fossil and Recent specimens of this taxon in terms of biostratinomic processes. This scarcity seems to be related to the shallower habitat of $M$. quinquiesperforata, which is under constant influence of both normal and storm waves. This reinforces the importance of the depositional setting and the role of physical processes, both related to the environmental context, on the preservation of dead remains in marine environment.

\section{ACKNOWLEDGEMENTS}

The author expresses his gratitude to J.H. Nebelsick, D.L. Meyer and a third anonymous reviewer for their comments and corrections that helped improve this paper. This work was made possible with the financial support (doctorship grant) from Conselho Nacional de Desenvolvimento Científico e Tecnológico - CNPq.

\section{REFERENCES}

Agassiz, L. 1841. Monographies d'Echinodermes, vivans et fossils. Neuchâtel , Edited by Louis Agassiz, 151 p.

Agassiz, A. 1872. Revision of the Echini. Illustrated Catalogue of the Museum of Comparative Zoology, Harvard University, 7(1):1-242.

Angulo, R.J.; Lessa, G.C. \& Souza, M.C. 2006. A critical review of mid- to late-Holocene sea-level fluctuations on the eastern Brazilian coastline. Quaternary Science Reviews, 25:486-506. doi:10.1016/j.quascirev.2005.03.008

Assine, M.L. \& Perinotto, J.A. 2001. Estratigrafia de sequências em sistemas deposicionais siliciclásticos costeiros e marinhos. In: H.J.P.S. Ribeiro (ed.) Estratigrafia de Sequências Fundamentos e Aplicações, EDUNISINOS, p. 305-339.

Barros, F.C.R.; Calliari, L.J. \& Gianuca, N.M. 1994. Estudo preliminar da macrofauna bentônica da praia dos Concheiros, RS. Notas Técnicas, 7:33-37.

Bell, B.M. \& Frey, R.W. 1969. Observations on the ecology and the feeding and burrowing mechanisms of Mellita quinquiesperforata (Leske). Journal of Paleontology, 43:553-560.

Borzone, C.A. \& Griep, G.H. 1991. Características do sedimento superficial infralitoral da região costeira adjacente à desembocadura da Lagoa dos Patos, RS, Brasil. Pesquisas, 18(1):71-78.

Buchmann, F.S.C. 1994. Distribuição de fósseis pleistocênicos na zona costeira e plataforma continental interna no Rio Grande o Sul. Acta Geologica Leopoldensia, 39(1):355-364.

Buchmann, F.S.C. 1996. Invertebrados fósseis (Crustacea, Echinodermata e Annelida) encontrados no cascalho biodetrítico (pós-praia) na porção sul da Planície Costeira, RS. Notas Técnicas, 9:21-27.

Buchmann, F.S.C. 2002. Bioclastos de organismos terrestres e marinhos na praia e plataforma interna do Rio Grande o Sul: natureza, distribuição, origem e significado geológico. Programa de Pós-Graduação em Geociências, Universidade Federal do Rio Grande do Sul, Ph.D. thesis, 108 p.

Buchmann, F.S.C. \& Rincón Filho, G. 1997. Fósseis de vertebrados marinhos do Pleistoceno Superior na porção sul da Planície Costeira do Rio Grande do Sul, Brasil. Notas Técnicas, 10:7-16.

Calliari, L.J. \& Fachin, S. 1993. Laguna dos Patos. Influência nos depósitos lamíticos costeiros. Pesquisas, 20(1):57-69.

Capitoli, R. 1998. Bentos da Plataforma Continental. In: U. Seeliger; C. Odebrecht \& J.P. Castello (eds.) Os Ecossistemas Costeiro e Marinho do Extremo Sul do Brasil, Editora Ecoscientia, p. 131-134.

Clark, H.L. 1940. A revision of the keyhole urchins (Mellita). Proceedings of the United States National Museum, 89:435-444.

Cooper, J.A.G. 1991. Beachrock formation in low latitudes: implications for coastal evolutionary models. Marine Geology, 98:145-154.

Cunha, F.L.S. 1959. Mamíferos fósseis do Pleistoceno do Rio Grande do Sul. I - Ungulados. Departamento Nacional da Produção Mineral, Divisão de Geologia e Mineralogia, p. 1-47 (Boletim 202).

Dillenburg, S.; Esteves, L.S. \& Tomazelli, L.J. 2004. A critical evaluation of coastal erosion in Rio Grande do Sul, Southern Brazil. Anais da Academia Brasileira de Ciências, 76(3):611-623.

Donovan, S.K. 1991. The taphonomy of echinoderms: calcareous multi-element skeletons in the marine environment. In: S.K. Donovan (ed.) The Processes of Fossilization, Belhaven Press, p. 241-269.

Durham, J.W. 1966. Clypeasteroids. In: R.C. Moore (ed.) Treatise on Invertebrate Paleontology, Part U, Echinodermata 3, University of Kansas Press, v. 2, 331 p.

Easton, W.H. 1960. Invertebrate Paleontology. New York, Harper \& Brothers, $701 \mathrm{p}$. 
Figueiredo Jr., A.G. 1975. Geologia dos depósitos calcários biodetríticos da plataforma continental do Rio Grande do Sul. Programa de Pós-Graduação em Geociências, Universidade Federal do Rio Grande do Sul, M.Sc. thesis, 72 p.

Ghiold, J. 1989. Species distribution of irregular echinoids. Biological Oceanography, 6:79-162.

Gianuca, N.M. 1998. Invertebrados bentônicos da praia. In: U. Seeliger; C. Odebrecht \& J.P. Castello (eds.) Os Ecossistemas Costeiro e Marinho do Extremo Sul do Brasil, Editora Ecoscientia, p. 127-130.

Gibson, M.A. \& Watson, J.B. 1989. Predatory and non-predatory borings in echinoids from the upper Ocala Formation (Eocene), north-central Florida, U.S.A. Palaeogeography, Palaeoclimatology, Palaeoecology, 71:309-321.

Godolphim, M.F.; Artusi, L.; Dehnhardt, B.A.; Villwock, J.A. \& Esteves, I.R.F. 1989. Novas evidências da transgressão holocênica na porção média da planície costeira do Rio Grande do Sul. Acta Geologica Leopoldensia, 12(29):23-36.

Harold, A.S. \& Telford, M. 1990. Systematics, phylogeny and biogeography of the genus Mellita (Echinoidea: Clypeasteroida). Journal of Natural History, 24:987-1026.

Hopkins, T.S. \& Ventura, C.R.R. 2000. The many "facies" of Encope emarginata (Leske). In: M.F. Barker (ed.) ECHINODERMS 2000 - INTERNATIONAL CONFERENCE, 10, 2000. Proceedings, Dunedin, p. 453-457.

Hsiou, A.S. \& Fortier, D.C. 2007. Primeiro registro de Caiman (Crocodylia, Alligatoridae) para o Pleistoceno do Estado do Rio Grande do Sul, Brasil. Gaea, 3(1):37-44.

Kier, P.M. 1977. The poor fossil record of the irregular echinoids. Paleobiology, 3:168-174.

Kier, P.M. 1981. A bored Cretaceous echinoid. Journal of Paleontology, 55(3):656-659.

Kier, P.M. 1982. Rapid evolution in echinoids. Palaeontology, 25(1):1-9.

Kroh, A. \& Nebelsick, J.H. 2010. Echinoderms and Oligo-Miocene carbonate systems: potential applications in sedimentology and environmental reconstruction. Gent, International Association of Sedimentologists, p. 201-228 (Special Publication 42).

Lopes, R.P. \& Buchmann, F.S.C. 2008. Comparação tafonômica entre duas concentrações fossilíferas (shell beds) da planície costeira do Rio Grande do Sul, Brasil. Gaea 4(2):65-77. doi: 10.4013/gaea.20082.03

Lopes, R.P. \& Buchmann, F.S.C. 2010. Pleistocene mammals from the southern Brazilian continental shelf. Journal of South American Earth Sciences, 31:17-27. doi:10.1016/j.jsames.2010.11.003

Lopes, R.P.; Buchmann, F.S.C. \& Caron, F. 2006. Primeiro registro de fósseis de aves marinhas na planície costeira do Rio Grande do Sul, Brasil. Revista Brasileira de Geociências, 36:648-650.

Lopes, R.P.; Oliveira, L.C.; Figueiredo, A.M.G.; Kinoshita, A.; Baffa, O. \& Buchmann, F.S.C. 2010. ESR dating of Pleistocene mammal teeth and its implications for the biostratigraphy and geological evolution of the coastal plain, Rio Grande do Sul, southern Brazil. Quaternary International, 212(2):213-222. doi:10.1016/j.quaint.2009.09.018

Marcon, G.T.G. 2007. Contribuição ao estudo dos Proboscidea (Mammalia, Gomphotheriidae) do Quaternário do Estado do Rio Grande do Sul, Brasil. Programa de Pós-Graduação em Geociências, Universidade Federal do Rio Grande do Sul, M.Sc. thesis, $113 \mathrm{p}$.

Martinez, S. \& Mooi, R. 2005. Extinct and extant sand dollars (Echinoidea: Clypeasteroida) from Uruguay. International Journal of Tropical Biology, 53 (Supplement 3):1-7.
Mooi, R. 1989. Living and fossil genera of the Clypeasteroida (Echinoidea: Echinodermata): an illustrated key and annotated checklist. Washington, Smithsonian Institution Scholarly Press, 51 p. (Smithsonian Contributions to Zoology 488).

Nebelsick, J.H. 1995. Uses and limitations of actuopalaeontological investigations on echinoids. Geobios, 18:329-336.

Nebelsick, J.H.1999. Taphonomic comparison between recent and fossil sand dollars. Palaeogeography, Palaeoclimatology, Paleoecology, 149:349-358.

Nebelsick, J.H. 2004. Taphonomy of echinoderms: introduction and outlook. In: T. Heinzeller \& J.H. Nebelsick (eds.) Echinoderms: München, A.A. Balkema, p. 471-477.

Nebelsick, J.H. 2008. Taphonomy of Recent Clypeaster: implications for fossil assemblages. In: W. Ausich \& G. Webster (eds.) Paleobiology of Echinoderms, Indiana University Press, p. 114-128.

Nebelsick, J.H. \& Kowalewski, M. 1999. Drilling predation on recent clypeasteroid echinoids from the Red Sea. Palaios, 14:127-144.

Nebelsick, J.H. \& Kroh, A. 2002: The stormy path from life to death assemblages: the formation and preservation of mass accumulations of fossil sand dollars. Palaios, 17:378-394.

Nebelsick, J.H.; Schmid, B. \& Stachowitsch, M. 1997. The encrustation of fossil and recent sea-urchin tests: ecological and taphonomic significance. Lethaia, 30:271-284.

Neves, F.M. \& Bemvenuti, C.E. 2009. Variabilidade diária da zonação da macrofauna bentônica em praias arenosas do litoral norte do Rio Grande do Sul. Iheringia, Série Zoologia, 99(1):7181. doi:org/10.1590/S0073-47212009000100011

Oliveira, E.V. 1996. Mamíferos Xenarthra (Edentata) do Quaternário do Estado do Rio Grande do Sul, Brasil. Ameghiniana, 33(1):65-75.

Paula Couto, C. \& Cunha, F.L.S. 1965. Nota preliminar sobre o reconhecimento geo-paleontológico do Rio Grande do Sul. Rio de Janeiro, Departamento Nacional da Produção Mineral, Divisão de Geologia e Mineralogia, p. 49-50 (Boletim 40).

Phelan, T.F. 1972. Comments on the echinoid genus Encope, and a new subgenus. Proceedings of the Biological Society of Washington, 85(8):109-130.

Pitana, V.G. \& Ribeiro, A.M. 2007. Novos materiais de Propraopus Ameghino, 1881 (Mammalia, Xenarthra, Cingulata) do Pleistoceno Final, Rio Grande do Sul, Brasil. Gaea, 3(2):60-67.

Ribeiro, A.M. \& Scherer, C.S. 2009. Mamíferos do Pleistoceno do Rio Grande do Sul, Brasil. In: A.M. Ribeiro; S.G. Bauermann \& C.S. Scherer (orgs.) Quaternário do Rio Grande do Sul: Integrando Conhecimentos. Porto Alegre, Sociedade Brasileira de Paleontologia, p.171-192 (Monografias da Sociedade Brasileira de Paleontologia 1).

Richter, M. 1987. Osteichthyes e elasmobranchii (Pisces) da Bacia de Pelotas, Quaternário do Rio Grande do Sul, Brasil. PaulaCoutiana, 1:17-37.

Russell, R.J. \& McIntire, W.G. 1965. Southern Hemisphere beach rock. Geographical Review, 55:17-45.

Schäfer, W. 1972. Ecology and Palaeoecology of Marine Environments. Chicago, University of Chicago Press, 568 p.

Scherer, C.S. 2005. Estudo dos Camelidae (Mammalia, Artiodactyla) do Quaternário do Estado do Rio Grande do Sul, Brasil. Programa de Pós-Graduação em Geociências, Universidade Federal do Rio Grande do Sul, M.Sc. thesis, 176 p.

Schrock, R.R. \& Twenhoefel, W.H. 1953. Principles of Invertebrate Paleontology. New York, McGraw-Hill, 816 p.

Seilacher, A. 1979. Constructional morphology of sand dollars. Paleobiology, 5(3):191-221. 
Smith, A.B. 1980. The structure, function and evolution of tube feet and ambulacral pores in irregular echinoids. Palaeontology, 23(1):39-83.

Smith, A.B. 1984. Echinoid Palaeobiology. London, George Allen \& Unwin, $190 \mathrm{p}$.

Taylor. P.D. \& Wilson, M.A. 2002. A new terminology for marine organisms inhabiting hard substrates. Palaios, 17:522-525.

Telford, M. 1981. A hydrodynamic interpretation of sand dollar morphology. Bulletin of Marine Science, 31(3):605-622.

Telford, M. 1983. An experimental analysis of lunule function in the sand dollar Mellita quinquiesperforata. Marine Biology, 76:125-134.

Telford, M. \& Mooi, R. 1986. Resource partitioning by sand dollars in carbonate and siliceous sediments: evidence from podial and particle dimensions. Biological Bulletin, 171:197-207.

Tomazelli, L.J.; Dillenburg, S.R. \& Villwock, J.A., 2000. Late Quaternary geological history of Rio Grande do Sul coastal plain, southern Brazil. Revista Brasileira de Geociências, 30(3):474-476.

Villwock, J.A. \& Tomazelli, L.J. 1995. Geologia Costeira do RS. Notas Técnicas, 08:27-29.

Zinsmeister, W.J. 1980. Observations on the predation of the clypeasteroid echinoid, Monophoraster darwini, from the Upper Miocene Entrerrios Formation, Patagonia, Argentina. Journal of Paleontology, 54(5):910-912.

Received in November, 2010; accepted in September, 2011. 